January 2022

\title{
Book Review: Kathleen Campana and J. Elizabeth Mills' Create, Innovate, and Serve: A Radical Approach to Children's and Youth Programming
}

Mateo Campos-Seligman

San Jose State University, mcamposseligman@gmail.com

Follow this and additional works at: https://scholarworks.sjsu.edu/ischoolsrj

Part of the Collection Development and Management Commons, Educational Methods Commons, Information Literacy Commons, Other Education Commons, Scholarly Communication Commons, and the Scholarly Publishing Commons

\section{Acknowledgements}

Many thanks and appreciation to every single professor who has aided me throughout my MLIS journey and provided me with the tools and knowledge needed to make writing this review possible. I would especially like to shout out: Instructors José Aguiñaga, who indirectly challenged me to write and submit this for publishing, and Lisa Houde, who was kind enough to look this over and encourage its publication; as well as Charlie (I love you), Stevie (come home), Alex (I don't know if you'll read this), and finally, Jess Dang, who told an eighth grader once to never, ever stop writing - hopefully this counts as proof that I took that advice to heart.

\section{Recommended Citation}

Campos-Seligman, M. (2022). Book Review: Kathleen Campana and J. Elizabeth Mills' Create, Innovate, and Serve: A Radical Approach to Children's and Youth Programming. School of Information Student Research Journal, 11(2). https://doi.org/10.31979/2575-2499.110203 Retrieved from https://scholarworks.sjsu.edu/ischoolsrj/vol11/iss2/3

This article is brought to you by the open access Journals at SJSU ScholarWorks. It has been accepted for inclusion in School of Information Student Research Journal by an authorized administrator of SJSU ScholarWorks. For more information, please contact scholarworks@sjsu.edu. 


\section{Book Review: Kathleen Campana and J. Elizabeth Mills' Create, Innovate, and Serve: A Radical Approach to Children's and Youth Programming}

\section{Keywords}

children's and youth programming, Radical Change, public libraries

\section{Acknowledgements}

Many thanks and appreciation to every single professor who has aided me throughout my MLIS journey and provided me with the tools and knowledge needed to make writing this review possible. I would especially like to shout out: Instructors José Aguiñaga, who indirectly challenged me to write and submit this for publishing, and Lisa Houde, who was kind enough to look this over and encourage its publication; as well as Charlie (I love you), Stevie (come home), Alex (I don't know if you'll read this), and finally, Jess Dang, who told an eighth grader once to never, ever stop writing - hopefully this counts as proof that I took that advice to heart.

\section{About Author \\ Mateo Campos-Seligman (he/him) is a current Library and Information Science Master's candidate at San Jose State University with hopes to further his aspirations of working in children's and youth services in a $\mathrm{K}-12$ or public library. His research interests include accessible youth-driven programming, educational technology, environmental and mobility justice, geography and urban studies, storytelling, and punk rock. He currently lives in a basement in Alameda, California, with his partner and dog.}


Campana, K., \& Mills, J. E. (Eds.). (2019). Create, innovate, and serve: A radical approach to children's and youth programming. Ala Neal-Schuman.

Campana and Mills' Create, Innovate, and Serve: A Radical Approach to Children's and Youth Programming provides a passionate, accessible, and grounded discussion of the current state and ideal future of children's and youth programming in libraries. It is meant, first and foremost, as a reference text for current Master of Library and Information Science (MLIS) students intending to enter the fields of children's and youth services. Published in 2019, this text is produced and compiled by Dr. Kathleen Campana and J. Elizabeth Mills. Campana is an assistant professor at the Kent State University School of Information in the field of youth services. J. Elizabeth Mills is a Ph.D. candidate at the University of Washington Information School and a children's book author.

Campana and Mills' intent is clear: they want to support the current master's candidates of Library and Information Science (LIS) in becoming the compassionate, flexible, radical, and knowledgeable children's and youth services librarians of today and tomorrow. The origins of this book began in 2015, when Campana and Mills co-taught an MLIS course at the University of Washington entitled Libraries as Learning Labs in the Digital Age. In setting out to compile texts to support the class's curriculum, the two authors searched for a text that would provide a broad scope of programming for children and youth from birth through the age of eighteen. They also wanted a text that included the professional input of both academics and passionate professionals who are currently working in, or implementing, radical children's and youth programming in some way within their professional spaces. "We wanted a book that would emphasize the importance of diversity, learning through play, outreach, and community in every aspect of what children's librarians do every day," the two scholars tell us in their introduction. As part of the process of creating the resource they were searching for, Campana and Mills sought to answer three key questions:

1. What would current library school students and future children's librarians like to know about the cognitive and sociocultural development of children at different stages of life?

2. What are libraries offering in terms of innovative, radical programming for children and teens?

3. What are the major studies and publications in the library and information science field that pertain to, support, and expand upon current practice in the field? (Campana \& Mills, 2019, pp. 157)

As is often the case in information science, seeking out the answer to these questions eventually resulted in a comprehensive project intended to provide an entry point to and broad overview of the ways today's librarians are providing creative, innovative, and participatory programming for children and young adults, utilizing the late Dresang's theory of Radical Change (1999) as their theoretical framework.

Through the use of Dresang's information age principles of connectivity, interactivity, and access (Dresang \& Koh, 2009), Campana and Mills describe how librarians embrace young adult and children's programming in this new digital 
world. Decades later, Dresang's original information age principles continue to inform how scholars approach design thinking for children and young adults and the radical content found in new texts meant for their age demographic. These principles, along with Dresang's three recommendations for types of radical change-changing formats, changing perspectives, and changing boundaries-make up the foundation and lens through which Campana and Mills present the various examples of radical approaches to children's and youth programming that are found within this book's pages.

While the authors wryly note that Dresang would encourage the reader to interact with the text "radically and synergistically, skipping around, reading what fits with what [they] need to know in the moment, and not necessarily reading in a linear fashion" (Campana \& Mills, 2019, pp. 18), the book is organized into two distinct parts. Part I focuses on the seven critical areas necessary for effective youth programming: diversity, storytelling, play and production, media mentorship, assessment, outreach and partnerships, and advocacy. This provides a grounding foundation the reader can then utilize when creating their own programs and services to meet the needs of digital age youth. The chapters in this section stress the importance of the library as an informal learning space for children and youth; this informality allows the library to expand past traditional literary programming and into a more hands-on, learner-motivated environment. This section draws on the expertise and contributions of librarians and academics around the country, as well as reliable and concrete research in youth learning and development and gives the reader an in-depth analysis of how these key areas are essential to modern-day learning. One such example is Naidoo's contribution on the importance of intentionally inclusive and diverse programming. Here, Naidoo argues the necessity of such programming for children and young adults, and the way it speaks to the needs of young people, on two fronts: representation and inclusivity for underrepresented patrons who deserve to see their stories told, and representation of those historically underrepresented for those who would not have a chance to encounter these more inclusive narratives otherwise.

This concept has been echoed by several other LIS professionals and academics in recent years, most notably by youth-focused professionals such as Bernier (2019), Cart (2016), and Houde (2018). Other voices from the LIS field that are cited in Part I include Goldsmith and Martin on the power of storytelling, Ward and Evans sharing a play-based framework that is useful to youth programming, Koester and Haines discussing the importance of digital media, Gross with information on how to evaluate youth programs and whether they are effective, and Crist and Nelson discussing outreach and advocacy. In addition to being leading voices within the LIS field when it comes to radical children's and youth programming, these contributors also cite studies and papers produced by the aforementioned scholars Bernier, Cart, and Houde, among others.

Part II then takes these ideas and contextualizes them in the real world with information drawn from research on youth socialization and development and case studies contributed by libraries that are currently implementing them in their children's and youth programming. The questions posed by Campana and Mills are answered through these case studies. Part II is divided into three sections: Early 
childhood (ages from birth to five), middle childhood (ages five to twelve), and teens (ages thirteen to eighteen). Each section is anchored by a review of learning and developmental theories relevant to each age group. Then, using these theories, Campana and Mills present tangible and real-world examples of how these ideas positively impact the learning that occurs through radical, digital-conscious youth and children's library programming. These case studies, or program profiles per Campana and Mills, include contributions from librarians around the country who have used the studies presented in Part I to further the success of their home libraries' youth programs.

By organizing the text into these two distinct parts, Campana and Mills present an incredibly accessible and informative compilation of information that will surely aid any MLIS student on their own learning journey, regardless of whether they eventually work with young people. In outlining their seven critical areas of learning and providing practical applications of those areas, Campana and Mills offer a template for learner-directed, community-first library programming. This text is meant to be used as a foundation to begin from as well as an inspiration for those planning to enter the field to specifically aid young people on their growing and learning journeys. However, one gap in the research presented in this book worth noting is that the subject matter does not branch farther than public libraries in the United States. While this book is a great tool that can be used by school librarians, or any youth-facing information professionals, its scope and focus is that of the interests of its publisher, the American Library Association. Scholars interested in international youth services and programming studies will need to search for a handbook elsewhere.

Ultimately, Campana and Mills provide a wealth of knowledge and information to lean on as we look forward into the future of radical LIS programming, weathering changing technologies, shifting demographics, and new generations of learners. Campana and Mills sum up the point of the book they made best: "This is the end of this book, but it's the beginning of an innovative, serviceoriented approach to creating library programming for children and youth. This is your call to action" (Campana \& Mills, 2019, pp. 408).

\section{References}

Bernier, A. (2019). Transforming young adult services. Chicago: ALA-Neal Schuman.

Campana, K., \& Mills, J. E. (Eds.). (2019). Create, innovate, and serve: A radical approach to children's and youth programming. ALA Neal-Schuman.

Cart, M. (2016). Young adult literature: From romance to realism. ALA NealSchuman.

Dresang, E. T. (1999). Radical change: Books for youth in a digital age. H.W. Wilson Co.

Dresang, E. T., \& Koh, K. (2009). Radical change theory, youth information behavior, and school libraries. Www.ideals.illinois.edu, 58(1). http://hdl.handle.net/2142/15294 
School of Information Student Research Journal, Vol. 11, Iss. 2 [2022], Art. 3

Houde, L. (2018). Serving LGBTQ teens: A practical guide for librarians (pp. 19; 71-91). Rowman \& Littlefield. 